日本臨床麻酔学会第 27 回大会パネルディスカッション

小児麻酔の知識スタンダード

小児心臓麻酔の基礎

$\begin{array}{lll}\text { 竹内 } & \text { 護*1 } & \text { 多賀直行 } \\ \text { 大塚洋司 } & \text { 岡田 } & \text { 修 } \\ \text { 篠原貴子 } & \text { 瀬尾憲正 } \\ \end{array}$

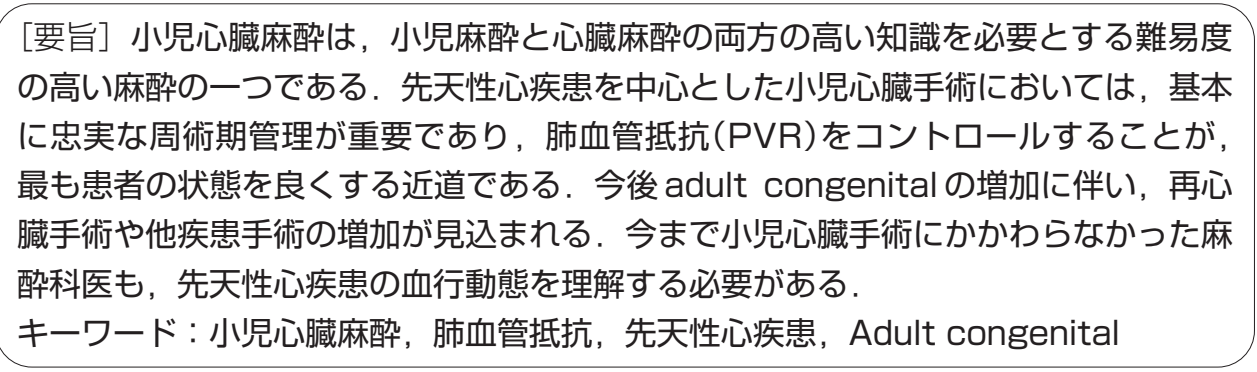

（日臨麻会誌 Vol.28 No.4, $578 ＼mathrm{~ 582, ~ 2008) ~}$

\section{はじめに}

小児心臓麻酔は，小児麻酔と心臓麻酔の両方の高 い知識を必要とする比較的難易度の高い麻酔の一種 である. 小児麻酔，心臓麻酔とも外科医からの要求 のレベルが高く, 麻酔専門医かつ熟練した麻酔科医 に麻酔管理が求められることも多い. 小児心臓麻酔 は多くの薬剤が使用され繊細な麻酔管理を要求され るが，決して細かいだけの麻酔ではない，両方の麻 酔のダイナミックさも兼ね備えており, 知識と経験 の少ない未熟な医師が行うと短時間に患者の状態が 悪くなるが, 熟練した医師が行うと短時間で患者の 状態を良くすることができるのが大きな魅力でもあ る。小児心臓麻酔の研修は卒業後 10 年までに受け るのが望ましいが，小児・心臓どちらかの麻酔経験
が十分であれば10年以降にでも可能である.

\section{I 先天性心疾患の考え方}

先天性心疾患は，まず非チアノーゼ性心疾患とチ アノーゼ性心疾患に分類される。また肺血流増加型 と減少型にも分類される。先天性心疾患の理解を難 しくしているのは，チアノーゼがありながら肺血流 が増加している疾患の存在である。例えば，総肺静 脈還流異常症 (TAPVD)，大血管転位症(TGA)，左 心低形成症候群(HLHS) など新生児期，乳児早期に 緊急手術の対象となる疾患である。しかし，こうい った疾患を除くと，チアノーゼのない疾患は肺血流 が増加し, チアノーゼ性疾患は肺血流が減少してい ると考えてよい.

先天性心疾患と成人の後天性心疾患との大きな違
著者連絡先 竹内 護

干 329-0498 下野市薬師寺 3311-1

自治医科大学とちぎ子ども医療センター
小児手術・集中治療部

自治医科大学とちぎ子ども医療センター
小児手術・集中治療部

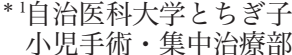

*2自治医科大学麻酔科学・集中治療医学講座 
いは，先天性では肺体血流比 (Qp/Qs)が1でない症 例が多いことである。したがって，肺血流のコント ロール，すなわち肺血管抵抗 (pulmonary vascular resistance : PVR)のコントロールが最も重要であ り，この点が管理の基本である。また同一の患者でも 人工心肺 (あるいは人工心肺を用いない手術) 前後で PVRの管理方法を変える必要がある。代表的疾患の 人工心肺(手術) 前後のPVRの管理を表 1 に示した.

\section{II 麻酔方法 1),2)}

準備段階としての気管チューブの選択は，新生児 $3.5 \mathrm{~mm}, 1$ 歳 $4.5 \mathrm{~mm}, 6$ 歳 $6.0 \mathrm{~mm}$ を目安にする。現 在の満期産の新生児の 3 分の 2 以上は $3.5 \mathrm{~mm}$ の気管 挿管が可能である。よい麻酔管理・術後管理のため にはリークが最小限に抑えられる最適なチューブの 選択が重要である。

最近, 心臓麻酔に使用される静脈麻酔薬の選択肢 が増加したが，小児心臓麻酔では軽症例では何を使 用してもよいが, 重症例では心筋抑制の少ない, か つ $\mathrm{Qp} / \mathrm{Qs}$ を変化させない麻酔薬を使用すべきであ る。この点で，最も適切な麻酔薬はフェンタニルで あり, 次いで $0.1 \sim 0.2 \mu \mathrm{g} / \mathrm{kg} / \mathrm{min}$ 程度の低用量のレ ミフェンタニルである。レミフェンタニルをこれ以 上高用量使用すると, 心拍数の減少が小児にとって は不利となる。吸入麻酔薬も単独でなければ使用可 能であり, 循環動態の変動の激しい小児心臓麻酔に とっては血圧の調節などに使用しやすい麻酔薬であ る。プロポフォール，チオペンタールは心筋抑制が 強く, 血圧を低下させ, 少なくとも軽症例を除いて は禁忌に近いと考えるべきである。

麻酔導入は, 静脈が確保されている症例ではフェ ンタニル $10 \mu \mathrm{g} / \mathrm{kg}$ とパンクロニウム $0.1 \sim 0.15 \mathrm{mg}$ / $\mathrm{kg}$ の静注にて行うが，パンクロニウムの代わりにベ クロニウム $0.1 \sim 0.2 \mathrm{mg} / \mathrm{kg}$ とアトロピン $0.1 〜$ $0.15 \mathrm{mg} / \mathrm{kg}$ の静注でも可能である。静脈が確保され ていない症例では, GOS (笑気一 50 \%酸素一セボフ ルラン) slow inductionにて患者を就眠させ，静脈う

\section{表 1 代表的疾患の人工心肺 (手術) 前後の肺血管抵抗}

\begin{tabular}{l|l|l}
\hline 人工心肺 & 後PVR $\uparrow$ & 後PVR $\downarrow$ \\
\hline 前PVR $\uparrow$ & HLHSの Norwood 手術, & VSD+PH, CAVSD, \\
& PDA 依存性疾患のBT & ECD, 新生児開心根治 \\
& shunt & 術 (TGA arterial \\
& & switch, TAPVD, \\
& & Truncus, CoA, IAA \\
& & complex, AP window) \\
\hline 前 PVR $\downarrow$ & TOFのBT shunt & TOF根治術 \\
\hline
\end{tabular}

インを確保後，セボフルランの投与を中止し上記薬 剤を投与する。ファロー四徵症 $(\mathrm{TOF})$ で低酸素発作 (anoxic spell)のある症例では 100 \%酸素吸入下に導 入を行うか，重症例では導入前に点滴を確保すべき である。

挿管された気管チューブの深さは，声門部で確実 に喉頭展開して, 新生児 $3 \mathrm{~cm}$ (口角で $9 \mathrm{~cm}$ ), 乳児 $4 \mathrm{~cm}$, 幼児 $5 \mathrm{~cm}, 10$ 歳以上 $6 \mathrm{~cm}$ が目安である. 術後, 一晚以上人工呼吸する症例においては，この時点で 経鼻抻管に切り替える。術後は出血, 低拍出症候群 (low output syndrome : LOS)などで循環動態が不 安定となる可能性があるからである。また，経鼻挿 管は術中TEEの操作を行うためにも有利である. 経鼻挿管の場合，気管チューブの深さは経口の約 1.2 倍となっている。

先天性心疾患では麻酔導入後に低血圧をきたす症 例が少なくない．これに対する麻酔管理は，まず血 液ガス分析を行いPVRの管理を厳重にすることで あり, 膠質液 $5 \mathrm{~m} l / \mathrm{kg}$ の反復投与, 塩化カルシウム $\left(\mathrm{CaCl}_{2}\right)$ の投与などにて対処する。麻酔維持は，主 にフェンタニルの追加投与と低濃度の吸入麻酔薬に て行う。フェンタニルの総投与量は，新生児で 50 $\mu \mathrm{g} / \mathrm{kg}$, 乳児以上で $20 \sim 30 \mu \mathrm{g} / \mathrm{kg}$ 程度であるが, 早期抜管症例ではより一層の減量を図る。レミフェ ンタニル $0.1 \sim 0.2 \mu \mathrm{g} / \mathrm{kg} / \mathrm{min}$ の併用も有用である. 人工心肺中はミダゾラム $5 \sim 10 \mathrm{mg}$ を人工心肺回路 内に投与する。仝肺中の血管拡張薬はクロルプ ロマジン (初回 $0.6 \mathrm{mg} / \mathrm{kg}$, ただし無血充填症例では 
$0.3 \mathrm{mg} / \mathrm{kg}$ )を第一選択とする。灌流圧は，新生児 30 〜 45, 乳児 $35 \sim 50$, 幼児 $35 \sim 55 \mathrm{mmHg}$ を目標にす る。早期抜管の適応は, 乳児中期以降の根治術 (ASD, VSD，TOF)，すべてのGlenn手術， Fontan 手術，体重 $5 \mathrm{~kg}$ 以上のBT shuntなどである. 肺高血圧症 $(\mathrm{PH})$ と中等度以上の弁逆流残存の症例 は，早期抜管は禁忌である。

これらの麻酔管理において, 超音波経食道心エコ ー (TEE) は必須のモニターである. TEEは心機能, 手術残存病変の評価にきわめて有用であることは周 知のとおりであるが，左心系の空気を視覚的に除去 することが可能であり, 空気塞栓の予防にも必須で ある。この情報公開の時代, 心臓外科医も自分の手 術を自画自賛するだけでなく, 多くの医師に画像で 公開し評価を受け，必要であれば即座に追加の手術 を行うことが重要だと考える。

\section{III 血管作動薬 ${ }^{33}$}

カテコラミンや血管拡張薬の使用は，PVRのコン トロールにも，また心不全症状軽減のためにも周術 期管理のうえできわめて重要な位置を占めている. 各カテコラミンのPVRに対する作用を表2 に示す. 乳児期以降の通常の手術では, 術後はドパミン $5 \mu \mathrm{g} /$ $\mathrm{kg} / \mathrm{min}$ の投与で十分であるが，大動脈遮断時間が 長い症例や $\beta$ 受容体の少ない新生览症例では追加の カテコラミン投与が必要となる。 小児心臓手術後に は，現在ドブタミン，エピネフリン，PDE III 阻害薬 の併用の 3 つの選択肢がある。筆者らが推奨するの は，動脈圧が高い場合にはPDE III 阻害薬，低い場 合にはエピネフリンの併用である。成人心蔵手術や 敗血症ショック時に使用されるノルエピネフリンは 末梢循環を増悪させるので，小児心臓手術にはあま り使用しない.

術後の肺高血圧症に対する血管拡張薬の第一選択 はニトログリセリンであり，第二選択は $\mathrm{PGE}_{1}$ であ る(表3)。これらの使用によっても対処が難しい重 症の肺高血圧症には，一酸化窒素(nitric oxide : NO)
表2 カテコラミンのPVRに対する作用

\begin{tabular}{ll}
\hline - Dopamine : & やや上昇 \\
- Dobutamine : & 低下 \\
- Isoproterenol : & 低下 \\
- Epinephrine : & 少量不変も上昇 \\
- Norepinephrine : & 著明に上昇 \\
\hline
\end{tabular}

表 3 血管拡張薬の作用の相違

\begin{tabular}{lcc}
\hline & $\begin{array}{c}\text { Dose for } 15 \% \\
\text { decrease in PVR }\end{array}$ & $\begin{array}{c}\text { \% decrease in } \\
\text { SVR at this dose }\end{array}$ \\
\hline Nitroglycerin & $6.1 \mu \mathrm{g} / \mathrm{kg} / \mathrm{min}$ & $9.0 \%$ \\
$\mathrm{PGE}_{1}$ & $0.097 \mu \mathrm{g} / \mathrm{kg} / \mathrm{min}$ & $14.0 \%$ \\
$\mathrm{PGI}_{2}$ & $10.6 \mathrm{ng} / \mathrm{kg} / \mathrm{min}$ & $15.3 \%$ \\
$\mathrm{SNP}$ & $1.9 \mu \mathrm{g} / \mathrm{kg} / \mathrm{min}$ & $24.0 \%$ \\
\hline
\end{tabular}

〔Kermode JL : Vasodilator drugs in infants after cardiac surgery, 1991, Melbourne University より引用]

吸入療法が有用である。肺高血圧発作 (PH crisis) の危険性の高い患者に対しては，通常麻薬と筋弛緩 薬の静注による鎮静と不動化が必要である。この場 合成人開心術後の鎮静とは異なり, PH crisis 予防の ためには筋弛緩薬の併用は必須である。PH crisisが 起こったときは，過換気や血管拡張薬とカテコラミ ンの増量で対処するが，膠質液を投与する場合は左 心房圧(LAP) ラインから投与する。右心系からの投 与は状態を改善しないので，推奨はできないがLAP ラインがない場合には動脈圧ラインからの投与も有 効である。

ファロー四徵症 $(\mathrm{TOF})$ の麻酔管理の要点は, anoxic spellの予防である.PVRを低下させる呼吸 管理を行い，膠質液を十分に投与することが予防の 最大のポイントである。浅麻酔はspell を誘発する が，過度の深麻酔も右一左シャントを増加させ低酸 素を助長する. Anoxic spell時の対策は，(1)膠質液 の投与，(2) $\alpha$-stimulant (メトキサミン，フェニレ フリン)の投与，(3)短時間作用性 $\beta$ 遮断薬 (塩酸ラン ジオロール）の投与，の順序である。膠質液の投与 
を十分に行わないと $\alpha$-stimulant や $\beta$ 遮断薬の効果 も限定的である. 術後は通常心拍出量は良好で早期 抜管は可能である。肺動脈狭窄 (PS) や肺動脈弁逆流 (PR)の残存の強い症例では, 術後の右室圧 (RVP), 中心静脈圧 $(\mathrm{CVP})$ が高く右心不全をきたす。左心系 の発育の悪い症例では, 術後LAPが高く左心不全 をきたす。術前の心エコー検査で左心系が 80 \%未 満の症例では要注意である.

\section{IV 最近の文献から}

小児心臓麻酔に関する最近の英語論文の主なもの を取り上げると, 肺高血圧と薬剤, preconditioning, 左心低形成症候群の RV-PA shunt と BT shunt, Chylothorax, Glenn術後の脳血流などがあげられる. Bidirectional superior cavopulmonary anastomosis (Glenn) 術後において hypercapnia は脳, 上大静脈 (SVC), 肺血流を増加し ${ }^{4}, \mathrm{PaO}_{2}$, 体血流, 脳血流 を増加させ，全血管抵抗(SVR)を低下させる ${ }^{5)}$ 。ま た $\mathrm{PaO}_{2}$ を改善し, 酸素消費量を低下させ, 動脈血

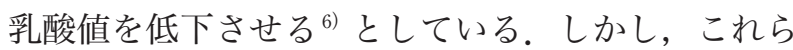
の報告はGlenn術後に鎮静下に人工呼吸管理で測定 されたものであり, Glenn術後管理の基本である早 期抜管との比較ではない. またGlenn 手術, Fontan 手術の適応に関して, 欧米ではPVRの高い症例は 移植というオプションもあるが, 日本にはなく, 本 邦の症例がより難易度が高いと思われる。すべての 症例を救命するためには, PVRを低下させる呼吸管 理と早期抜管という基本に忠実な管理が重要ではな いだろうか.

\section{おわりに}

TOF 根治術はもちろんであるが, Jatene 手術や Norwood 手術などのように, 従来救命することがで
きなかった小児が，多数成人を迎える時代になって 来ている.いわゆる adult congenitalの増加が今後 の大きな問題の一つであろう。再心臓手術や他疾患 手術の増加が見込まれる。したがって，今まで小児 心臓手術にかかわらなかった麻酔科医も，少なくと も心臓手術を行う施設においては，先天性心疾患の 血行動態を勉強する必要が出てくるのではないだろ うか.

最後に, 先天性心疾患を中心とした小児心臓手術 においては，基本に忠実な周術期管理が重要であり， 肺血流のコントロール，すなわち肺血管抵抗(PVR) を上手にコントロールすることが，最も患者の状態 を良くする近道である。

\section{参考文献}

1）森田潔, 竹内護, 多賀直行ほか：小児心臟麻酔マニュ アル. 岡山大学医学部附属病院麻酔科蘇生科編. 岡山, 2007

2) Lake CL : Pediatric Cardiac Anesthesia, 3rd ed. Appleton \& Lange, Stanford, 1998

3）竹内護, 岩崎達雄, 戸田雄一郎ほか : 小児心臟手術に 抢ける血管作動薬の使用法. 麻酔 54 ：S119-S126, 2005

4) Bradley SM, Simsic JM, Mulvihill DM : Hypoventilation improves oxygenation after bidirectional superior cavopulmonary connection. J Thorac Cardiovasc Surg $126: 1033-1039,2003$

5) Hoskote A, Li J, Hickey C, et al. : The effects of carbon dioxide on oxygenation and systemic, cerebral, and pulmonary vascular hemodynamics after the bidirectional superior cavopulmonary anastomosis. J Am Coll Cardiol 44 : 1501-1509, 2004

6) Li J, Hoskote A, Hickey C, et al. : Effect of carbon dioxide on systemic oxygenation, oxygen consumption, and blood lactate levels after bidirectional superior cavopulmonary anastomosis. Crit Care Med 33 : 984989, 2005 


\title{
The Basic of Pediatric Cardiac Anesthesia
}

\author{
Mamoru TAKEUCHI ${ }^{* 1}$, Naoyuki TAGA*1, Osamu OKADA*2, \\ Yoji OTSUKA *1, Takako SHINOHARA *2, Norimasa SEO*2 \\ ${ }^{*}$ Pediatric Operating Suite and Intensive Care Unit, Jichi Children’s Medical Center Tochigi \\ ${ }^{* 2}$ Department of Anesthesiology and Critical Care Medicine, Jichi Medical University
}

Pediatric cardiac anesthesia is one of the most difficult types of anesthesia, and requires sufficient knowledge of both pediatric and cardiac anesthesia. It is best for the pediatric cardiac surgery patients if pulmonary vascular resistance is controlled as much as possible. Almost every anesthesiologist should understand the hemodynamics of each congenital heart disease, as the number of adult patients with congenital heart diseases will increase in the near future.

Key Words : Pediatric cardiac anesthesia, Pulmonary vascular resistance, Congenital heart disease, Adult congenital

The Journal of Japan Society for Clinical Anesthesia Vol.28 No.4, 2008 